\title{
Short Communication \\ Leonotis leonurus L. R. Br. (Lamiaceae): Anatomical features and recreational use survey of a possible substitute for Cannabis sativa $\mathrm{L}$. (Cannabaceae)
}

[Leonotis leonurus L. R. Br. (Lamiaceae): Estudio de características anatómicas y uso recreativo de un posible sustituto de Cannabis sativa L. (Cannabaceae)]

\author{
Ignacio J. Agudelo, Karina Borri, Leonardo M. Anconatani, Cecilia B. Dobrecky, \\ Marcelo L. Wagner \& Rafael A. Ricco \\ Cátedra de Farmacobotánica, Departamento de Farmacología, Facultad de Farmacia y Bioquímica, \\ Universidad de Buenos Aires, Argentina \\ *Correspondence to: ignacioagudelo@yahoo.com.ar
}

\begin{abstract}
Leonotis leonurus L. R. Br. (Lamiaceae) is a medicinal plant native to the South African continent also employed as a recreational drug and a substitute to Cannabis sativa L. (Cannabaceae). Given the interest of the last mentioned species as a source of treatments for epilepsy among many other pathologies and its possible substitution for $L$. leonurus, the aim of this article is obtain anatomical and micrographical characters for its identification in chopped or powdered material and to survey the user's perceptions about this plant based in posts extracted from a recreational drug user Internet forum. $L$. leonurus leaves have pluricellular tector trichomes and two classes of pluricellular trichomes with unicellular and pluricellular heads, styloid crystals in its mesophyll among many other characters, while the flowers have wooly trichomes and characteristic pollen granules. Regarding the Internet forum survey, it was reported that $L$. leonurus leaves and flowers were the employed parts and that the mode of use was smoked. The reported effect was sedative. The anatomical data reported in this article may help to identify L. leonurus in pharmaceutical or forensic contexts.
\end{abstract}

Keywords: Leonotis leonurus; Cannabis sativa; Legal highs; Plant anatomy.

Resumen: Leonotis leonurus L. R. Br. (Lamiaceae) es una planta medicinal originaria del continente sudafricano que también se emplea como droga recreativa y sustituto del Cannabis sativa L. (Cannabaceae). Dado el interés de la última especie mencionada como fuente de tratamientos para la epilepsia entre muchas otras patologías y su posible sustitución por L. leonurus, el objetivo de este artículo es obtener caracteres micrográficos y anatómicos para su identificación en material picado o pulverizado y relevar las percepciones del usuario sobre esta planta basadas en publicaciones extraídas de un foro de Internet de usuarios de drogas recreativas. Las hojas de L. leonurus tienen tricomas tectores pluricelulares y dos clases de tricomas pluricelulares con cabezas unicelulares y pluricelulares, cristales estiloides en su mesófilo entre muchos otros caracteres, mientras que las flores tienen tricomas lanudos y gránulos de polen característicos. Con respecto a la encuesta del foro de Internet, se informó que las hojas y flores de L. leonurus eran las partes empleadas y que el modo de uso era ahumado. El efecto informado fue sedante. Los datos anatómicos informados en este artículo pueden ayudar a identificar $L$. leonurus en contextos farmacéuticos o forenses.

Palabras clave: Leonotis leonurus; Cannabis sativa; Colorantes legales; Anatomía vegetal. 


\section{INTRODUCTION}

Given the recent approval of Cannabis sativa L. (Cannabaceae) medicinal products for the treatment of diseases such as epilepsy and chronic pain, there have been many issues regarding the quality of the raw material that could be potentially employed for the elaboration of medicinal products (Hazekamp, 2006; Fischedik et al., 2010; Peschel, 2016). This situation is aggravated since $C$. sativa is a highly variable species and presents different chemotypes as a result of geographical distribution and environmental conditions (Hillig, 2004).

The quality of medicinal plants needs to be assessed and the possible substitutions need to be known since it is a problem with an impact on public health. Substitutions or adulterations of medicinal species are a common issue in the quality control of these products, and there have been many cases which illustrate the need of a strict vigilance based on scientific evidence (Wu et al., 2007; Selvam, 2012).

Leonotis leonurus L. R.Br. (Lamiaceae) (Figure No. 1) is a semi perennifolius bush native to South Africa, though it has a cosmopolitan distribution as an ornamental species. It has opposite, pubescent, narrowly ovate to linear petiolate leaves with narrowly acute apex and cuneate base, and a serrated margin. It has orange flowers with a tubular corolla and a pale green calyx (Vos, 1995). The flowers are arranged in a globose inflorescence. It is known as "lion's tail", "lion's ear", "wild dagga", "klip dagga" and its potential use as a C. sativa substituent is suggested by the names "marihuanilla" and "wild cannabis". There is bibliographical evidence of its use as a substituent of the aforementioned species, and is employed in South African folk medicine for the treatment of a wide range of ailments such as ulcers, snake bites and respiratory diseases. Its flowers and leaves are smoked for the treatment of epilepsy and partial paralysis; this practice replaces tobacco smoking and it is said to produce feelings of well being, joy, visual changes, nausea and dizziness (Nsuala et al., 2015).

These species contain labdane diterpenoid compounds, of which marrubiin is the most studied (He et al., 2012; Wu et al., 2013). Both the organic extract and marrubiin have a cardioprotective effect tested in animal models by suppressing platelet aggregation and inflammatory markers (Mnonopi et al., 2011). Its antidiabetic activity has also been tested in animal models (Mnonopi et al., 2012).

Other studies suggest that labdane diterpenoids have an inhibitory action in central nervous system receptors. The antiepileptic activity of the leaf infusion was performed in animal models with pentylenetetrazole and picrotoxin induced seizures (Bienvenu et al., 2002).

L. leonurus is considered a "legal high": a psychotropic product that can be sold in stores because it is not present in any list of banned products (Gorun et al., 2010). However, it can be mixed with synthetic products (such as synthetic cannabinoids) to enhance its potency (Fattore \& Fratta, 2011).

The aim of this study is to obtain anatomical and micrographical characters of flowers and leaves of L. leonurus for the identification in commercial or forensic samples, and to obtain a consumer's profile based on information extracted from an spanish-speaking Internet forum.

\section{METHODOLOGY}

\section{Plant material}

Samples of L. leonurus were collected in Valeria del Mar, Provincia de Buenos Aires, República Argentina $\left(37^{\circ} 08^{\prime} 22.0^{\prime \prime S}\right.$ $56^{\circ} 52^{\prime} 26.1 \mathrm{WW}$ ) and identified against taxonomic keys (Dimitri, 1972; Vos, 1995). Herbarium specimens were made and a voucher specimen is present in the BAF herbarium under the number IJA006.

\section{Anatomical and micrographical studies}

Cross sections: The material was fixed with the FAA reactive. Free hand sections were obtained by cutting transversely the material with a razor blade. Cuts were treated with comercial bleach for the emptying of the cellular contents and dehydrated in an ethanol-water series. Safranin-Fast Green differential staining was used, 30 minutes for the first dye and 1 minute for the second. 
Micrographical studies: Plant material was macerated by boiling it for 10 minutes in $5 \% \mathrm{w} / \mathrm{v} \mathrm{NaOH}$, washed with purified water and looked under the microscope. In order to confirm the characters observed in the macerate, leaves were observed under a scanning electron microscope. Briefly, dry samples were treated with gold-palladium in a sputter coater Thermo VG Scientific SC 7620. A microscope Philips model XL30 TMP New Look was used.

For further technical information about the employed techniques, please refer to (Gurni, 2014).

\section{Recreational use survey}

Information was extracted from www.cannabiscafe.net, an spanish speaking Internet forum of cannabis and hallucinogenic substances users. A search was performed from January 2003 to January 2020 with the following terms; "Leonotis leonurus", "Wild dagga", "Klip dagga", "Cola de león" and "Marihuanilla" (Figure No. 1). Selected threads and their answers were selected and the information was sorted by the following categories: Effect, Mode of use and Part used. When in doubt, the posts were discussed between the authors in order to reach consensus.

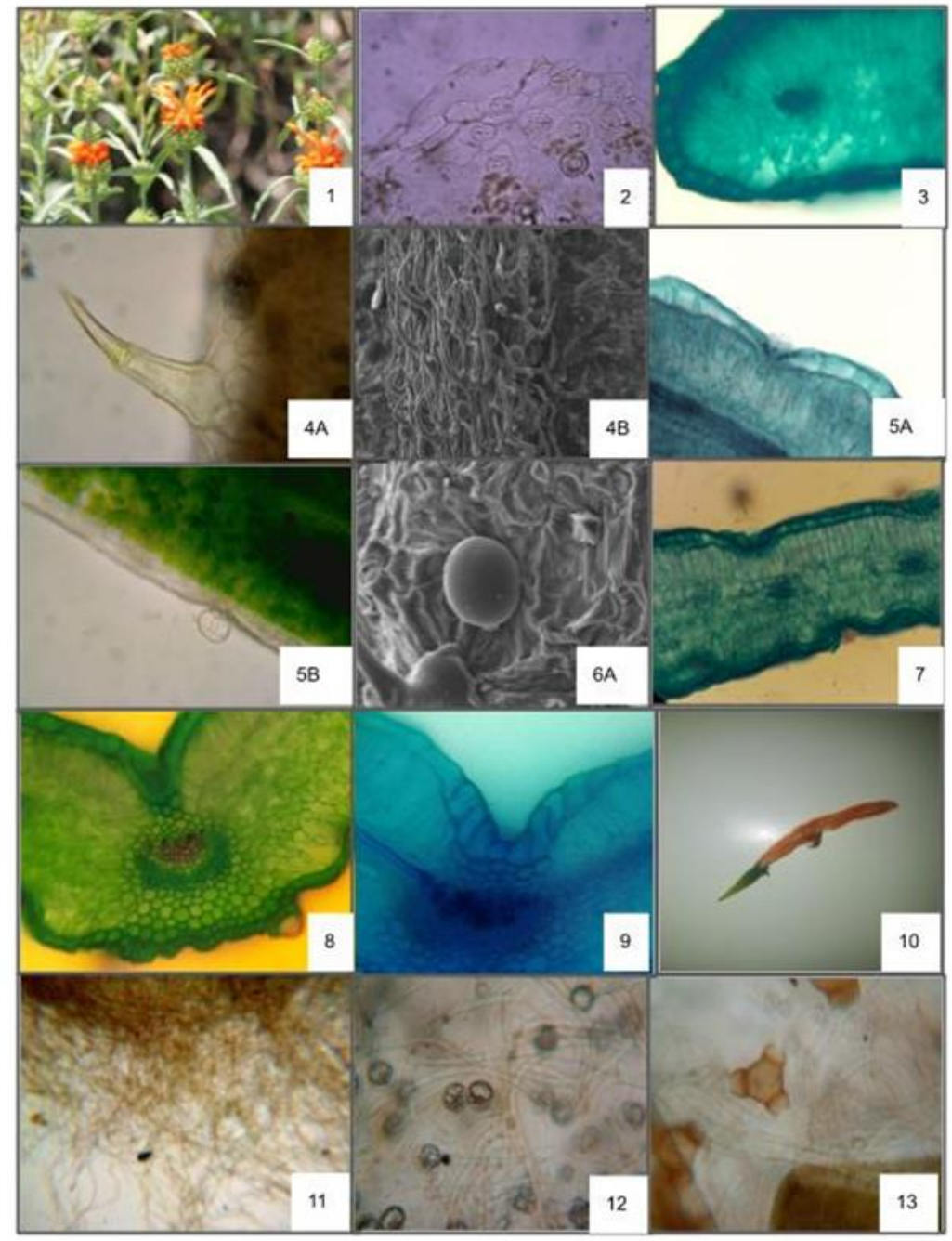

Figure No. 1

Inflorescence of $L$. leonurus; 2: Anisocytic stomata (400X); 3: Detail of an stomata cavity in cross sections (400X); 4A and B: Tector pluricellular trichome (400x and 1000X); 5A and B: Detail of glandular trichomes with pluricelular heads (400x and 1000X); 6: Glandular trichomes with unicellular heads(400X); 7: Mesophyll

(200X); 8: Central venation (200X); 9: Detail of adaxial cells adjacent to the central venation (400X); 10:

Bilabiate flower; 11: Wooly trichomes present in flowers (200X); 12: Glandular trichomes (400X); 13: Pollen granules (400X) 


\section{RESULTS}

\section{Anatomical and micrographical characters}

The leaf is amphistomatic with unistrata epidermis in both adaxial and abaxial surfaces. (Figure No. 2) Adaxial epidermal cells are quadrangular and larger than the abaxial epidermal cells. The latter has anisocytic stomata in the same level (Figure No. 3).

The epidermis has simple pluricellular (2-3 cells) trichomes, $299 \pm 82 \mu \mathrm{m}$ long, with a higher density in the central vein (Figures No. 4A and No. 4B), and two classes of smaller glandular trichomes. The first ones have one basal cell with two cells in its head (Figure No. 5), while the second ones are unicellular both in head and base (Figure No. 6). Their lengths are $24 \pm 2 \mu \mathrm{m}$ and $32 \pm 5 \mu \mathrm{m}$, respectively. Both glandular trichomes are placed in epidermal invaginations in both epidermis.

Mesophyll tends to be isobilateral, with small styloid calcium oxalate crystals (Figure No. 7). Palisade parenchyma is a layer of cylindrical cells that comprises about 30\% of the total width. Spongy parenchyma has a layer of 5-7 cells with few intercellular spaces and a single layer of elongated cells adjacent to the abaxial surface.

The vascular bundle has 3-5 strata of annular collenchyma in its abaxial surface and is surrounded by a parenchymatous sheath (Figure No. 8). The ratio phloem/xylem is approximately 1:1. The adaxial epidermis adjacent to the vascular bundle has cells longer than the epidermal cells of the mesophyll (Figure No. 9).

The flower is bilabiate, orange and hermaphrodite (Figure No. 10). It has the same glandular and single trichomes, along with large wooly trichomes in both labia (Figure No. 11 and Figure No. 12). The pollen grain has an oblate shape with an axis shorter than the equatorial diameter (Figure 13).
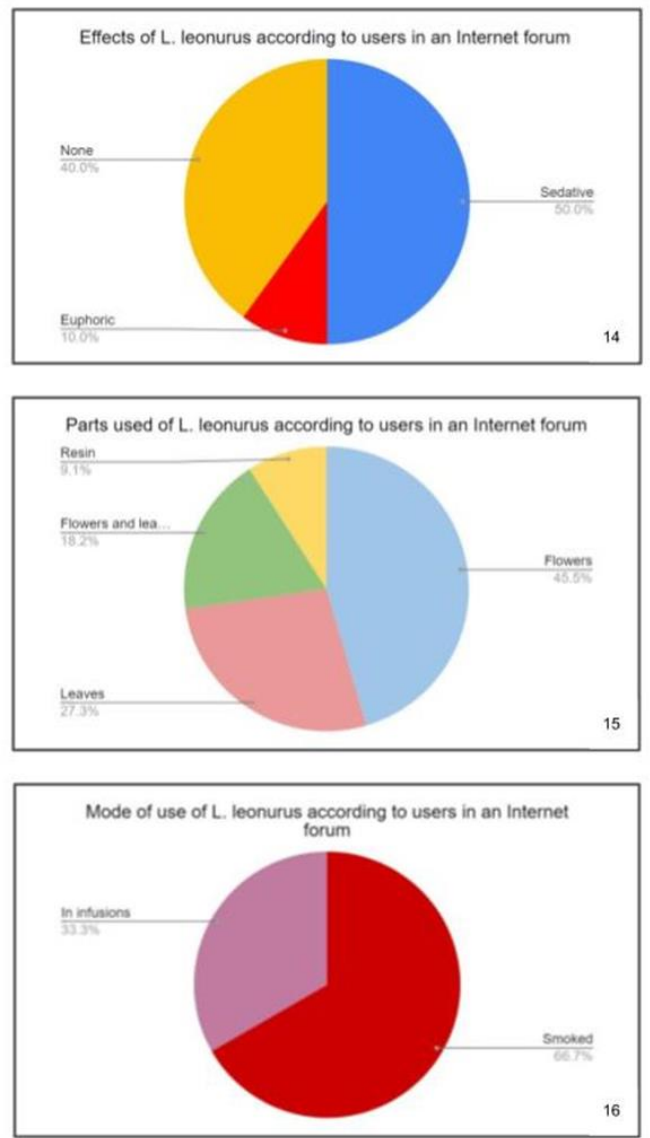

Figure No. 14: Survey about $L$. leonurus reported effects; 15: Survey about parts used; 16: Survey about mode of use 


\section{Recreational use survey}

During the search period there were a total of 3.167 .848 posts. 32 posts had the previously mentioned search terms. All the posts that did not include the botanical name or a picture where the plant could be recognized were discarded. Posts where the author claimed not to have used the plant were also discarded. In the remaining posts (11), information was sorted by categories. There were 9 mentions about the effect of L. leonurus, 8 mentions of its use and 11 mentions of its used part. Results are depicted in the Figures No. 14, 15 and 16.

\section{DISCUSSION}

The present study provides evidence of the possible use and micrographical identification parameters for the quality control of L. leonurus by means of different histological techniques. Its leaves contain glandular trichomes and single covering trichomes that can be employed to identify this species in powdered or fragmented material. Some of these anatomical features have been previously reported (Vos, 1995; Ascensao et al., 1997), though the information provided in this article contributes to a botanical identification of chopped material. Additional identifications through morphological (in case of whole plant material), genetic or phytochemical methodologies may be useful to confirm the botanical identity (Upton et al., 2020).

The survey found that the main parts used are flowers, followed by flowers and leaves, and leaves. Since it is employed as a substitute for $C$. sativa, users may use flowers as a replacement for $C$. sativa inflorescences. A small number of users mention a plant resin; however, no resin was found in this analysis and during the collection of the material.

The effect attributed to this plant is sedative, however, many users claim to have no effect at all and very few posts claim it to be an euphoric agent. It is usually smoked in pipes or cigarettes, though many users claim to use infusions. The latter is also mentioned in an ethnographic research performed with South African natives (Ott, 1996; Nsuala et al., 2015).

Nowadays C. sativa is a subject of intense research around the world in order to assess its efficacy and safety in complex pathologies such as pediatric refractory epilepsy and chronic pain, and the debate on self-cultivation (Szaflarski \& Bebin, 2014; Hill et al., 2017; Levinsohn \& Hill, 2020). This can lead to quality problems such as bioaccumulation of pollutants as a consequence of growth in contaminated areas, (MacPartland \& McKernan, 2017; Dryburgh et al., 2017). Substitution of medicinal plants might be also a problem, as it is for another species (Wu et al., 2007; Selvam, 2012; Sagar, 2014).

Hoffmann \& Schultes, in their book "Plant of the Gods" (Schultes et al., 2000), mention L. leonurus as a substitute for C. sativa. This publication, and the fact that native people use it for the treatment of epilepsy and as a recreational drug, support the possible substitution in the present context. L. leonurus does not have a prohibition in its use, but given that the safety and efficacy of this species is unknown it should not be employed, especially in the treatment of a complex pathology such as epilepsy. Besides, its use along with other recreational drugs must not be discarded (Zawilska, 2011) and there have been reports of its possible use as a psychoactive agent (Stogner, 2015).

\section{CONCLUSSION}

This article provides anatomical and micrographical information for the botanical identification of L. leonurus, a plant that might be a substituent of $C$. sativa. It also provides information regarding its uses and effects extracted from an Internet forum of recreational users. This data suggests that $L$. leonurus leaves and flowers are smoked mainly because of its sedative effect.

Further research is needed for the genetic and phytochemical characterization of possible substitutes of $C$. sativa in order to provide identification parameters in both pharmaceutical and forensic contexts.

\section{REFERENCES}

Ascensão L, Marques N, Pais MS. 1995. Glandular trichomes on vegetative and reproductive organs of Leonotis leonurus (Lamiaceae). Ann Bot 75: 619-626. https://doi.org/10.1006/anbo.1995.1067

Bienvenu E, Amabeoku GJ, Eagles PK, Scott G, Springfield EP. 2002. Anticonvulsant activity of aqueous extract of Leonotis leonurus. Phytomedicine 9: 217-223. https://doi.org/10.1078/0944-7113-00103 
Dimitri MJ. 1972. Enciclopedia Argentina de agricultura y jardinería, Tomo 1: Descripción de las plantas cultivadas. Ed. ACME, Buenos Aires, Argentina.

Dryburgh LM, Bolan NS, Grof CP, Galettis P, Schneider J, Lucas CJ, Martin JH. 2018. Cannabis contaminants: sources, distribution, human toxicity and pharmacologic effects. Brit J Clin Pharmacol 84: 2468-2476. https://doi.org/10.1111/bcp.13695

Fattore L, Fratta W. 2011. Beyond THC: the new generation of cannabinoid designer drugs. Front Behav Neurosci 5: 60. https://doi.org/10.3389/fnbeh.2011.00060

Fischedick JT, Hazekamp A, Erkelens T, Choi YH, Verpoorte R. 2010. Metabolic fingerprinting of Cannabis sativa L., cannabinoids and terpenoids for chemotaxonomic and drug standardization purposes. Phytochemistry 71 : 2058-2073. https://doi.org/10.1016/j.phytochem.2010.10.001

Gorun G, Dermengiu D, Curca GC, Hostiuc S, Ioan B, Luta V. 2010. Toxicological drivers issues in "legal highs" use. Romanian J Legal Med 18: 272.

Gurni AA. 2014. Técnicas histológicas en investigación. In: Zarlavsky GE. Histología vegetal. Técnicas simples y complejas. Editorial Sociedad Argentina de Botánica. Buenos Aires, Argentina.

Hazekamp A, Sijrier P, Verpoorte R. 2006. An evaluation of the quality of medicinal grade cannabis in the Netherlands. Cannabinoids 1: 1-9.

He F, Lindqvist C, Harding WW. 2012. Leonurenones A-C: Labdane diterpenes from Leonotis leonurus. Phytochemistry 83: 168-172. https://doi.org/10.1016/j.phytochem.2012.07.014

Hill KP, Palastro MD, Johnson B, Ditre J. W. 2017. Cannabis and pain: a clinical review. Cannabis Cannabinoid Res 2: 96-104. https://doi.org/10.1089/can.2017.0017

Hillig KW, Mahlberg PG. 2004. A chemotaxonomic analysis of cannabinoid variation in Cannabis (Cannabaceae). Am J Bot 91: 966-975. https://doi.org/10.3732/ajb.91.6.966

Levinsohn EA, Hill KP. 2020. Clinical uses of cannabis and cannabinoids in the United States. J Neurol Sci 411: 116717. https://doi.org/10.1016/j.jns.2020.116717

McPartland JM, McKernan KJ. 2017. Contaminants of concern in cannabis: microbes, heavy metals and pesticides. In: Chandra S, Lata H, ElSohly M. (eds) Cannabis sativa L. - Botany and Biotechnology. Springer, Cham. https://doi.org/10.1007/978-3-319-54564-6_22

Mnonopi N, Levendal RA, Davies-Coleman MT, Frost CL. 2011. The cardioprotective effects of marrubiin, a diterpenoid found in Leonotis leonurus extracts. J Ethnopharmacol 138: 67-75. https://doi.org/10.1016/j.jep.2011.08.041

Mnonopi N, Levendal RA, Mzilikazi N, Frost CL. 2012. Marrubiin, a constituent of Leonotis leonurus, alleviates diabetic symptoms. Phytomedicine 19: 488-493. https://doi.org/10.1016/j.phymed.2011.12.008

Nsuala BN, Enslin G \& Viljoen A. 2015. "Wild cannabis": a review of the traditional use and phytochemistry of Leonotis leonurus. J Ethnopharmacol 174: 520-539. https://doi.org/10.1016/j.jep.2015.08.013

Ott J. 1994. Pharmacotheon, drogas vegetales sus fuentes y su historia. La Liebre de Marzo, Barcelona, España.

Peschel W. 2016. Quality control of traditional cannabis tinctures: pattern, markers, and stability. Scientia Pharmaceut 84: 567-584. https://doi.org/10.3390/scipharm84030567

Sagar PK. 2014. Adulteration and substitution in endangered, ASU herbal medicinal plants of India, their legal status, scientific screening of active phytochemical constituents. Int J Pharmaceut Sci Res 5: 4023.

Schultes RE, Hofmann A, Ratsch C. 2000. Plantas de los dioses: orígenes del uso de los alucinógenos. Fondo de Cultura Económica, Ciudad de México, México.

Selvam ABD. 2010. Is the term substitution relevant to pharmacognosy and/or vegetable crude drug industry? Pharmacogn Res 2: 323.

Stogner JM. 2015. Predictions instead of panics: the framework and utility of systematic forecasting of novel psychoactive drug trends. Am J Drug Alcohol Abuse 41: 519-526. https://doi.org/10.3109/00952990.2014.998367

Szaflarski JP, Bebin EM. 2014. Cannabis, cannabidiol, and epilepsy from receptors to clinical response. Epilepsy \& Behavior 41: 277-282. https://doi.org/10.1016/j.yebeh.2014.08.135

Upton R, David B, Gafner S, Glasl S. 2020. Botanical ingredient identification and quality assessment: strengths and limitations of analytical techniques. Phytochem Rev 19: 1157-1177. https://doi.org/10.1007/s11101-019-09625-z

Vos W'T. 1995. A systematic study of Leonotis (Pers.) R. Br.(Lamiaceae) in southern Africa. Thesis, University of Natal, South Africa. 
Wu H, Li J, Fronczek FR, Ferreira D, Burandt Jr CL, Setola V, Roth BL, Zjawiony JK. 2013. Labdane diterpenoids from Leonotis leonurus. Phytochemistry 91: 229-235. https://doi.org/10.1016/j.phytochem.2012.02.021

Wu KM, Farrelly JG, Upton R, Chen J. 2007. Complexities of the herbal nomenclature system in traditional Chinese medicine (TCM): lessons learned from the misuse of Aristolochia-related species and the importance of the pharmaceutical name during botanical drug product development. Phytomedicine 14: 273-279. https://doi.org/10.1016/j.phymed.2006.05.009

Zawilska JB. 2011. Legal highs-new players in the old drama. Curr Drug Abuse Rev 4: 122-130. https://doi.org/10.2174/1874473711104020122 